\title{
PENGEMBANGAN MEDIA PEMBELAJARAN BIOLOGI BERBASIS POWTOON PADA MATERI SEL
}

\section{DEVELOPING BIOLOGY LEARNING MEDIA BASED ON POWTOON ON CELLS MATERIAL}

\author{
Aswar Akbar'1), Ahmad Ali'2), Salahuddin ${ }^{3)}$ \\ 1,2,3)Fakultas Tarbiyah dan Keguruan Universitas Islam Negeri Alauddin Makassar \\ aswar.kun199@gmail.com ${ }^{1}$, ahmad.ali@uin-alauddin.ac.id ${ }^{2}$, salahuddin@uin-alauddin.ac.id ${ }^{3)}$
}

\begin{abstract}
Abstrak
Pendidikan pada bangku persekolahan terkadang tidak bisa diterima secara totalitas oleh semua peserta didik, dikarenakan peserta didik mempunyai gaya belajar masing-masing sehingga memunculkan sebuah permasalahan dalam proses pembelajarannya, khususnya seorang guru kadang dalam proses mengajar di kelas masih sering menggunakan media papan tulis dan metode ceramah hingga membuat peserta didik merasa bosan dan tidak mampu memahami materi yang disampaikan oleh gurunya. Penelitian ini bertujuan untuk mengembangkan media pembelajaran biologi berbasis PowToon yang valid, praktis, dan efektif. Penelitian ini mengadaptasi model pengembangan 4-D yang meliputi empat tahap yakni define (pendefenisian), design (perancangan), develop (pengembangan), dan disseminate (penyebaran). Berdasarkan hasil penelitian, diketahui tingkat kevalidan media pembelajaran biologi berbasis PowToon berada pada kategori sangat valid dengan nilai rerata sebesar 3,66. Tingkat kepraktisan media pembelajaran biologi berbasis PowToon berada pada kategori sangat praktis dengan nilai rerata sebesar 3,53. Hasil tes peserta didik dikategorikan sangat efektif karena mencapai rata-rata hasil belajar 83,54 dengan interval $>80$ ). Sehingga media pembelajaran biologi berbasis PowToon layak digunakan karena memenuhi tiga kriteria yakni kevalidan, kepraktisan serta keefektifan. Media pembelajaran biologi berbasis PowToon diharapkan dapat diimplementasikan pada kegiatan pembelajaran di kelas.
\end{abstract}

Kata Kunci: pengembangan, media pembelajaran, PowToon

\begin{abstract}
Education in school is sometimes not acceptable in totality by all learners, because learners have their own learning style so that it raises a problem in the learning process, especially a teacher sometimes in the process of teaching in the classroom still often uses whiteboard media and lecture methods to make learners feel bored and unable to capture the material delivered by their teachers. This research aims to develop a valid, practical, and effective PowToon-based biological learning medium. This research adapts the 4-D development model which includes four stages namely define (defining), design (design), develop dessiminate. Based on the results of the study, it is known the the level of validity of the PowToon based biology learning media is in the valid category and the mean value is 3.66. The level of practicality of the PowToon based biology learning media is in the very practical category with an average value of 3.53 student test results are categorized as very effective because they achieve an average learning outcome of 83.54 with intervals (>80). So that the PowToon based biology learning media is feasible to use because it meets three criteria, namely validity, practicality and effectiveness. PowToon based biology learning media is expected to be implemented in classroom learning activities.
\end{abstract}

Keywords: development, learning media, PowToon 
How to Cite: Akbar, A., Ali, A., \& Salahuddin. (2021). Pengembangan media pembelajaran biologi berbasis PowToon pada materi sel. Al asma: Journal of Islamic Education, 3(2), 295305.

\section{PENDAHULUAN}

Pendidikan sebagai esensi kehidupan yang sangat vital bagi manusia agar bisa berkembang maupun bertumbuh baik secara logika, psikologis dan fisis (Bayraktar, 2013). Pendidikan memiliki nilai-nilai yang baik, benar serta mulia bagi kehidupan sebagai tujuan dari pendidikan tersebut. Oleh sebab itu, tujuan pendidikan memiliki dua fungsi yang dapat dijadikan sebagai patokan tercapainya tujuan pendidikan itu yakni mengarahkan kepada seluruh kegiatan dalam pendidikan dan sebagai tujuan akhir yang akan melalui serangkaian proses pendidikan (Rahardja \& Umar Dan, 2005).

Pendidikan yang dilakukan pada bangku persekolahan umumnya digunakan dalam mencerdaskan dan meningkatkan kualitas anak bangsa secara keseluruhan, pendidikan juga sebuah usaha manusia dengan penuh rasa tanggung jawab dalam mendewasakan peserta didik (Hamansah \& Hading, 2015). Pendidikan dilakukan secara sistematis dan penuh perencanaan guna menghasilkan kegiatan belajar yang efektif sehingga peserta didik dapat aktif dan memaksimalkan potensi dalam dirinya baik dalam bidang akademik, keterampilan, pengendalian diri, minat dan bakat (Saondi \& Suherman, 2015).

Materi ajar biologi ialah materi yang cukup sulit dipelajari karena objek kajiannya yang sangat luas dalam kehidupan. Oleh sebab itu, diketahui bahwa biologi mempunyai cabang-cabang keilmuan yang setiap kelompok organisme diklasifikasikan secara khusus seperti zoology, botani serta mikrobiologi serta dilihat dari dimensi isi/produk harus mampu menanamkan pengertian dan pemahaman secara luas tentang fakta, konsep dan materi (Siti Sapuroh, 2010). Terkadang dalam sebuah pendidikan pasti akan ada saja hambatan dalam proses pembelajarannya.

Pendidikan pada bangku persekolahan tidak bisa diterima secara maksimal oleh semua peserta didik hal ini dikarenakan daya tangkap dan gaya belajar mereka berbedabeda sehingga menimbulkan problematika eksternal dan internal, masalah internal yang dimaksud adalah masalah yang timbul dalam diri peserta didik contohnya kebiasaan belajar, kemampuan intelektual serta kemampuan penginderaan dan kemampuan mengingat sesuatu, motivasi, sedangkan problematika eksternal ialah problem peserta didik yang berasal dari faktor luar contohnya peralatan belajar, ruangan belajar dan lingkungan sosialnya (Priyayi et al., 2018). Adapun hakikat kesulitan dalam pembelajaran peserta didik dikarenakan adanya suatu faktor yang terlihat dalam menifestasi tingkah laku peserta didik, baik secara tidak langsung maupun secara langsung sesuai dengan tingkat kesulitan pembelajaran peserta didik tersebut (Muntari, 2015). Keberhasilan suatu proses pembelajaran peserta didik dapat dipengaruhi salah satunya faktor media.

Media adalah sarana bantu yang dipakai dalam mengirimkan pesan, menstimulus pikiran, batin, atensi, dan niat peserta didik agar terlibat dalam kegiatan belajar (Nor et al., 2021). Dikatakan terjadi proses pembelajaran apabila adanya di antara pendidik maupun peserta didik terjadi interaksi dan proses memberi dan menerima sebuah informasi dengan bantuan sumber daya yang tersedia misalnya media pembelajaran (Heryanto \& Rahayu, 2021). 
Media pembelajaran adalah unsur dalam kegiatan belajar-mengajar (KBM) untuk mentransfer informasi yang bisa diketahui dengan mudah oleh peserta didik (Lulut, Maulana \& Ali). Selain itu, media pembelajaran juga sarana penyampaian materi yang mampu dipakai oleh pendidik yang nantinya akan diajarkan pada peserta didik, selain meningkatkan atensi maupun creative skill peserta didik, dengan media ini juga menyokong peserta didik dalam menulis, memotivasi dalam belajar dan terampil dalam berbicara dan berimajinasi semakin meningkat (Tafonao, 2018). Jenis media pembelajaran diantaranya media cetak, audio visual, komputer, gabungan (Purwono, 2014), gambar, diagram, bagan dan grafik (Maimunah, 2016).

Penggunaan media dalam proses belajar mengajar tentunya harus memiliki perencanaan yang betul-betul matang sebelum nantinya akan disampaikan di ruang kelas sehingga kegiatan belajar mengajar mampu dilaksanakan secara baik, dalam mengelompokkan berbagai jenis media maka perlu dilihat dari sisi pengembangan teknologi yang terdiri dari 2 kategori yang luas yakni media tradisional dan media mutakhir (Setiyadi, 2017). Media pembelajaran yang diimplementasikan dengan tepat dalam pembelajaran akan menjadi efektif dan mendukung dalam menggapai sebuah tujuan pembelajaran, selain itu ia juga dapat menambah motivasi belajar (Puspitarini \& Hanif, 2019).

Berdasarkan hasil observasi yang telah dilaksanakan di kelas XI IPA di SMAN 1 Pinrang, khususnya pada pembelajaran biologi materi sel dalam proses pembelajarannya itu masih kurang dalam memanfaatMan media. media berupa papan tulis serta buku paket masih menajdi media utama sehingga berdampak pada peserta didik yang cepat bosan, kurang memahami dan menguasai materi yang disajikan.

Berdasarkan pokok permasalahan tersebut, maka dibutuhkan sesuatu media pembelajaran bersifat inovatif yang menarik perhatian siswa sehingga lebih memperhatikan dalam belajar serta aktif dalam mengikuti kegiatan belajar, sehingga siswa bukan sekedar membaca dan mendengarkan tetapi akan mendapatkan pemahaman yang maksimal. Hal tersebut bisa lebih meningkat dengan adanya sebuah media yang bersifat audiovisual di mana media ini mampu untuk menyampaikan sebuah informasi yang mampu untuk dilihat dan juga dapat didengarkan.

Media yang mampu untuk dimanfaatkan dalam proses belajar dengan materi sel adalah media PowToon. PowToon merupakan media berbasis perangkat lunak berupa presentasi animasi, di mana dalam media ini telah disiapkan dengan berbagai jenis efek animasi seperti animasi tangan, kartun dan efek transisi yang menarik dan unik, bukan hanya itu media ini bisa menggabungkan atau menambahkan teks, video, gambar, audio serta berbagai data yang lain (Fajar, 2017).

Penelitian dilaksanakan memiliki tujuan dalam mengembangkan media pembelajaran biologi berbasis PowToon pada materi sel SMAN 1 Pinrang, melihat tingkat validitas media pembelajaran biologi berbasis PowToon pada materi sel SMAN 1 Pinrang, melihat tingkat kepraktisan media pembelajaran biologi berbasis PowToon pada materi sel SMAN 1 Pinrang dan Melihat tingkat keefektifan media pembelajaran biologi berbasis PowToon pada materi sel SMAN 1 Pinrang.

Manfaat penggunaan media PowToon mendukung di saat mewujudkan proses pembelajaran yang efektif, membantu mengefesienkan proses pembelajaran, membuat kualitas pembelajaran meningkat, dan membuat sesuatu yang abstrak menjadi lebih 
konkret (Deliviana, 2017), sedangkan menurut Latifah \& Lazulva (2020) bahwa media ini mampu menarik perhatian serta merangsang motivasi belajar peserta didik menjadi baik lagi serta dapat mencerna materi pelajaran yang disajikan dengan lebih mudah.

\section{METODE PENELITIAN}

Jenis penelitian yang digunakan yaitu research and development yang memiliki tujuan melahirkan sebuah produk media pembelajaran PowToon yang bersifat valid, praktis dan efektif. Desain penelitian yaitu model 4-D yang memiliki empat tahapan, yaitu define, design, develop dan disseminate atau diadaptasikan menjadi model 4-P yaitu pendefinisian, perancangan, pengembangan, dan penyebaran (Arum, 2020). Model pengembangan 4-D digunakan karena cocok dijadikan landasan dalam mengembangkan media pembelajaran berbasis PowToon alurnya yang utuh, sistematis serta mengikutsertakan keputusan para ahlinya.

Subjek uji coba penelitian yaitu siswa kelas XI SMAN 1 Pinrang yang berjumlah 11 orang. Instrumen untuk menguji kevalidan media adalah memakai lembar validasi. Dan uji kepraktisan memakai angket respon pendidik dan peserta didik serta instrumen berupa butir soal untuk menguji tingkat kefektifan media.

Teknik analisis data dilaksanakan dengan uji kevalidan, uji kepraktisan serta uji keefektifan. Uji kevalidan melibatkan 2 orang validator. Teknik analisis data kevalidan yang digunakan dapat dilihat pada tabel.1

Keterangan:

$$
\overline{K i} \quad=\frac{\sum_{j}^{n}=1 V_{i j}}{n}
$$

$\overline{K i}=$ rata-rata kriteria ke-i

$V_{i j}=$ skor hasil penilaian terhadap kriteria ke-i oleh penilai ke-j

$\mathrm{N}=$ banyaknya penilai

Tabel 1. Kriteria Tingkat Kevalidan

\begin{tabular}{cc}
\hline Nilai & Kriteria \\
\hline $3,5<M \leq 4$ & Sangat valid \\
\hline $2,5<M \leq 3,5$ & Valid \\
\hline $1,5<M \leq 2,5$ & Cukup valid \\
\hline$M \leq 1,5$ & Tidak valid \\
\hline & Sumber: (Sugiyono, 2013)
\end{tabular}

Uji kepraktisan diketahui dari penilaian angket respon pendidik dan peserta didik Teknik analisis data dilihat pada tabel 2.

Keterangan:

$$
\mathrm{X}_{\mathrm{i}}=\frac{\sum_{i=0}^{n} A i}{n}
$$

$\mathrm{Ai}=$ rata-rata aspek
$\mathrm{n}=$ banyaknya aspek 
Tabel 2. Kriteria Tingkat Kepraktisan

\begin{tabular}{cc}
\hline Nilai & Kriteria \\
\hline $3,5 \leq \mathrm{X}_{\mathrm{i}} \leq 4$ & Sangat Positif \\
\hline $2,5 \leq \mathrm{X}_{\mathrm{i}} \leq 3,5$ & Positif \\
\hline $1,5 \leq \mathrm{X}_{\mathrm{i}} \leq 2,5$ & Cukup Positif \\
\hline $0 \leq \mathrm{X}_{\mathrm{i}} \leq 1,5$ & Tidak Positif \\
\hline Sumber: (Fitriani, Mustami \& Hamansah 2019)
\end{tabular}

Uji keefektifan media diukur berdasarkan soal tes yang berikan kepada peserta didik. Teknik analisis data keefektifan yang digunakan dapat dilihat pada tabel 3.

$$
\mathrm{N}=\frac{W}{n}
$$

Keterangan:

$\mathrm{N}=$ Nilai yang diperoleh siswa

$\mathrm{W}=$ Jumlah soal yang benar

$\mathrm{n}=$ Banyaknya item soal

Tabel 3. Kriteria Tingkat Keefektifan

\begin{tabular}{cc}
\hline Presentase Ketuntasan & Klasifikasi \\
\hline$X>80$ & Sangat efektif \\
\hline $60<X \leq 80$ & Efektif \\
\hline $40<X \leq 60$ & Cukup Efektif \\
\hline $20<X \leq 40$ & Kurang Efektif \\
\hline$X \leq 20$ & Sangat Kurang Efektif \\
\hline & Sumber: (Widoyoko, 2009)
\end{tabular}

\section{HASIL DAN PEMBAHASAN}

Pengembangan media pembelajaran biologi berbasis PowToon memakai model 4D dengan empat tahapan yaitu pendefenisian, perancangan, pengembangan dan penyebaran (Hardiyanti et al., 2020). Model 4-D digunakan karena sistematik, pemilihan model dilaksanakan secara sistematis dan sesuai dengan landasan teori yang ada, melalui model pembelajaran 4-D ditemukan upaya pemecahan masalah pembelajaran dalam kelas yang sesuai dengan permasalahan yang ada misalnya permasalahan sumber belajar dan bahan ajar (Arywiantari dkk., 2015).

Tahapan pertama adalah tahap pendefenisian (define), terdiri atas analisis awalakhir memiliki tujuan untuk memahami permasalahan yang dialami dan mencari solusi permasalahan (Nurdiyanti et al., 2017). Kemudian analisis kepribadian sampel uji coba, diketahui bahwa tingkat pemahaman peserta didik tergolong sedang, kemudian analisis konsep yang menjadi rujukan dalam menetapkan sub bab yang sesuai dengan materi. Selanjutnya analisis tugas yang sesuai dengan materi sel tahapan terakhir yaitu merumuskan tujuan pembelajaran.

Tahapan kedua adalah perancangan (design) untuk menyiapkan prototype I PowToon. Tahapan tersebut digunakan untuk memilih media serta menentukan semua aspek-aspek yang terkandung di dalam media yang akan dikembangkan meliputi pemilihan bentuk dan ukuran media. 
Tahapan ketiga yaitu pengembangan (develop). Peneliti telah menghasilkan prototype I setelah itu validasi oleh 2 validator yang bertujuan dalam mendapatkan saran dan masukan. Hasil saran dan masukan 2 validator pada tabel 4.

Tabel 4. Saran dari Validator 1 dan 2

\begin{tabular}{|c|c|}
\hline \multicolumn{2}{|c|}{$\begin{array}{r}\text { Saran dan Masukan Validator } \\
\end{array}$} \\
\hline $\begin{array}{l}\text { Validator } 1 \\
\text { Sebelum revisi } \\
\end{array}$ & $\begin{array}{c}\text { Validator } 1 \\
\text { Setelah revisi } \\
\end{array}$ \\
\hline $\begin{array}{l}\text { 1. Tidak terdapat KD dan tujuan pembelajaran } \\
\text { pada media PowToon }\end{array}$ & $\begin{array}{l}\text { 1. Sudah terdapat KD dan tujuan } \\
\text { pembelajaran pada media PowToon }\end{array}$ \\
\hline $\begin{array}{l}\text { 2. Tidak terdapat identitas yang menunjukkan } \\
\text { bahwa itu mediamu }\end{array}$ & $\begin{array}{cccc}\text { 2. } & \text { Sudah terdapat identitas } \\
\text { menunjukkan bahwa itu mediamu }\end{array}$ \\
\hline $\begin{array}{c}\text { Validator 2 } \\
\text { Sebelum revisi } \\
\end{array}$ & $\begin{array}{c}\text { Validator } 2 \\
\text { Setelah revisi } \\
\end{array}$ \\
\hline $\begin{array}{l}\text { 1. Perbaiki penulisan yang belum sesuai } \\
\text { sistematika penulisan }\end{array}$ & $\begin{array}{l}\text { 1. Penulisan sudah sesuai sistematika } \\
\text { penulisan }\end{array}$ \\
\hline 2. Tambahkan gambar pada organel - organel sel & $\begin{array}{l}\text { 2. Sudah ditambahkan gambar pada organel - } \\
\text { organel sel }\end{array}$ \\
\hline $\begin{array}{l}\text { 3. Tambahkan materi perbedaan difusi dan } \\
\text { osmosis pada media PowToon }\end{array}$ & $\begin{array}{l}\text { 3. Sudah ditambahkan materi perbedaan } \\
\text { difusi dan osmosis pada media PowToon }\end{array}$ \\
\hline $\begin{array}{l}\text { 4. Cari gambar yang lebih bagus baik sel hewan } \\
\text { dan sel tumbuhan }\end{array}$ & $\begin{array}{l}\text { 4. Sudah diganti gambar yang lebih bagus baik } \\
\text { sel hewan dan sel tumbuhan }\end{array}$ \\
\hline $\begin{array}{l}\text { 5. Suara pengguna pada media jangan terburu- } \\
\text { buru }\end{array}$ & $\begin{array}{l}\text { 5. Suara pengguna pada media sudah tidak } \\
\text { terburu-buru }\end{array}$ \\
\hline
\end{tabular}

Setelah melakukan perbaikan media sesuai saran dan masukan maka didapatkan prototype II yang sudah valid untuk diujicobakan. Hasil prototype II pada Gambar 1.

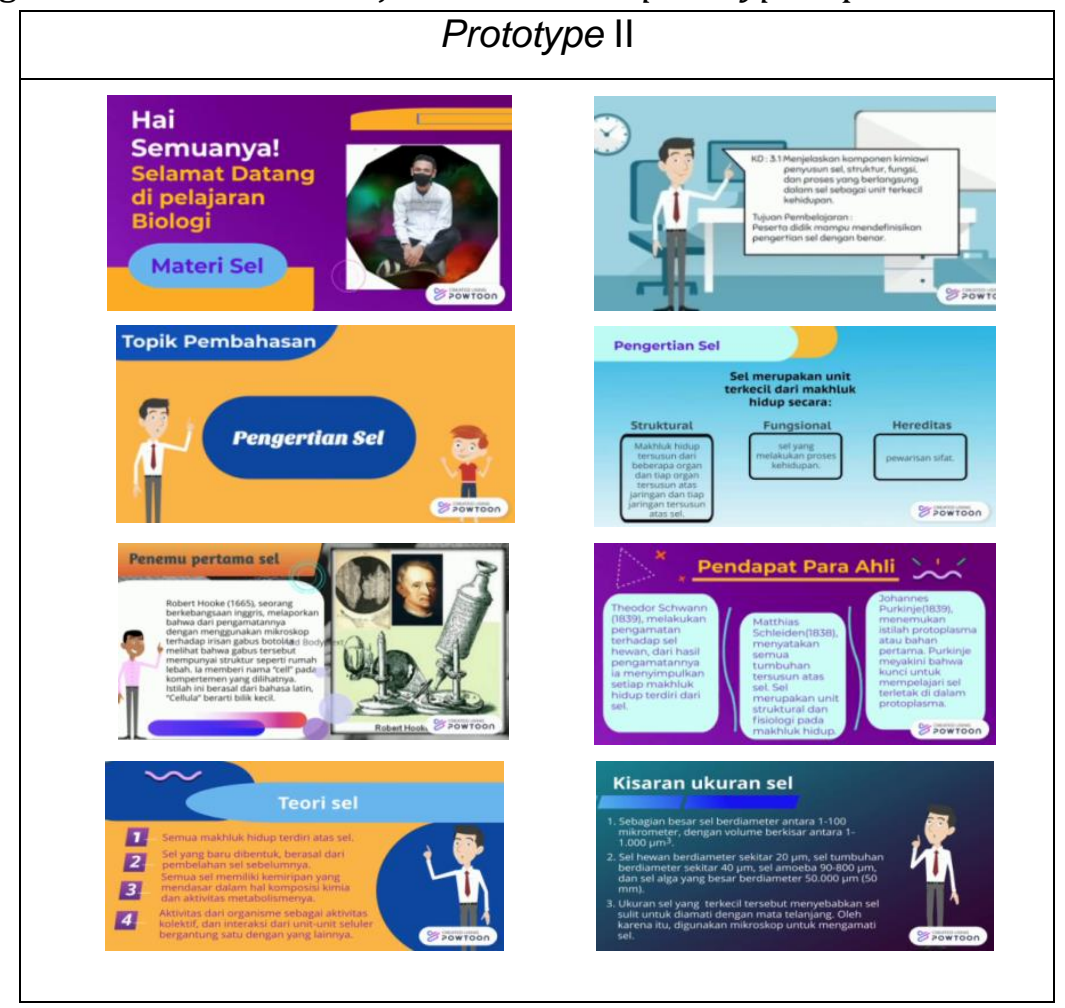

Gambar 1. Prototype II 
Tahap keempat yaitu penyebaran (disseminate), peneliti melaksanakan uji coba terbatas di kelas XI IPA 8 SMAN 1 Pinrang. Uji coba digunakan dalam mendapatkan pengetahuan sejauh mana PowToon dapat digunakan di kelas. Jumlah siswa pada kelas XI IPA 8 berjumlah 30, namun karena keadaan yang tidak memungkinkan disebabkan adanya COVID-19 maka jumlah siswa yang hadir berjumlah 11 orang. Adapun hasil penilaian validator pada tabel 5 .

Tabel 5. Rata-Rata Penilaian Validator

\begin{tabular}{|c|c|c|c|}
\hline \multirow{2}{*}{$\begin{array}{c}\text { No } \\
\text { Item }\end{array}$} & \multirow[t]{2}{*}{ Aspek Yang Dinilai } & \multicolumn{2}{|c|}{ Penilaian Validator } \\
\hline & & Validator 1 & Validator 2 \\
\hline \multicolumn{4}{|c|}{ Isi Media Pembelajaran PowToon } \\
\hline 1. & $\begin{array}{llll}\text { a. Kesesuaian isi } & \text { PowToon } & \text { dengan } \\
\text { kompetensi dasar } & \text { (KD) dan } & \text { tujuan } \\
\text { pembelajaran } & & & \\
\end{array}$ & 4 & 4 \\
\hline 2 & $\begin{array}{l}\text { b. Kata yang dibuat ditinjau dari aspek } \\
\text { keilmuan }\end{array}$ & 4 & 3 \\
\hline 3. & c. Kejelasan topik pembelajaran & 4 & 4 \\
\hline & Rata-rata & 4 & 3,6 \\
\hline \multicolumn{4}{|c|}{ Aspek Kebahasaan/Komunikasi } \\
\hline 1. & $\begin{array}{l}\text { a. Kesesuaian bahasa dengan tingkat } \\
\text { berpikir siswa }\end{array}$ & 4 & 3 \\
\hline 2. & $\begin{array}{l}\text { b. Kemampuan mendorong rasa ingin tahu } \\
\text { peserta didik }\end{array}$ & 4 & 4 \\
\hline & Rata-rata & 4 & 3,5 \\
\hline \multicolumn{4}{|c|}{ Aspek Penyajian } \\
\hline 1. & a. Tampilan media menarik & 4 & 3 \\
\hline 2. & b. Diberi judul/ keterangan media & 4 & 4 \\
\hline & Rata-rata & 4 & 3,5 \\
\hline \multicolumn{4}{|c|}{ Efek Bagi Strategi Pembelajaran } \\
\hline 1. & a. Kemudahan penggunaan & 4 & 4 \\
\hline 2. & $\begin{array}{l}\text { b. Dukungan media bagi kemandirian } \\
\text { belajar peserta didik }\end{array}$ & 3 & 4 \\
\hline 3. & 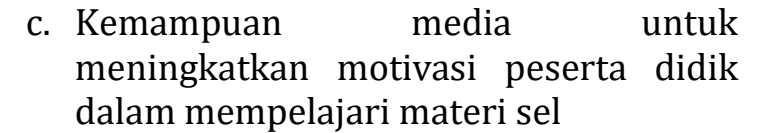 & 3 & 3 \\
\hline 4. & $\begin{array}{l}\text { d. Kemampuan media menambah } \\
\text { pengetahuan }\end{array}$ & 4 & 3 \\
\hline & Rata-rata & 3,5 & 3,5 \\
\hline \multicolumn{4}{|c|}{ Tampilan Menyeluruh } \\
\hline 1. & $\begin{array}{ll}\text { a. } & \begin{array}{l}\text { Kemenarikan desain } \\
\text { pembelajaran PowToon }\end{array} \\
\end{array}$ & 4 & 3 \\
\hline 2. & b. Keteraturan desain PowToon & 3 & 3 \\
\hline 3. & $\begin{array}{l}\text { c. Pemilihan jenis animasi dan tamplate } \\
\text { mendukung media menjadi lebih } \\
\text { menarik }\end{array}$ & 4 & 4 \\
\hline 4. & d. Pemilihan warna dengan baik & 4 & 3 \\
\hline & Rata-rata & 3,75 & 3,25 \\
\hline
\end{tabular}


Kevalidan media pembelajaran PowToon berada pada nilai rata-rata 3,66 (sangat valid). Kriteria yang dipakai dalam menetapkan jika media mempunyai derajat validitas yang baik medapatkan skor rerata 1,5 $\leq M \leq 2,5$ dengan kriteria cukup (Zaenal Arifin, 2017). Ketika skor dengan rentang $3,5<M \leq 4$ maka dapat dikatakan sangat valid (Sugiyono, 2013).

Media peneliti dikatakan sangat valid dikarenakan berbagai faktor yaitu kurikulum yang digunakan sudah sesuai, peserta didik memiliki motivasi untuk belajar dan aktif dalam kegiatan pembelajaran, serta Kegiatan belajar terfokus pada peserta didik (Dwijayani, 2017). Media juga dikatakan sangat valid jika mendapat penilaian yang baik dari aspek materi dan aspek media (Listiani \& Prihatnani, 2018).

Produk dikatakan valid apabila semua komponen dalam pembelajaran saling terlibat dalam media, sehingga produk tersebut dapat dimanfaatkan dengan baik (Fayanto et al., 2019). Selain itu, adapun keunggulan media PowToon diantaranya: interaktif, mencakup semua aspek keterampilan, praktis digunakan, bersifat kolaboratif, dapat digunakan dalam kelompok besar peserta didik, dapat mendorong peserta didik untuk mau belajar (Megawati \& IGALP, 2020). Sehingga membuat proses pembelajaran semakin menyenangkan.

Kepraktisan media pembelajaran PowToon diketahui dari angket respon peserta didik dan pendidik, angket respon peserta didik didapatkan skor rerata 3,46 dan angket respon pendidik didapatkan skor rerata 3,6. Total hasil respon keseluruhan dari angket peserta didik dan pendidik adalah 3,53 tergolong pada kategori sangat praktis pada interval $\left(3,5<\mathrm{X}_{\mathrm{i}} \leq 4\right)$. PowToon dikatakan praktis dilihat dari penggunaannya yang simple utamanya bagi seorang pemula (Masita \& Wulandari, 2018).

Kepraktisan sebuah media dapat dilihat dari pengguna produk baik itu guru, pendidik dan ahli lainnya yang tidak mengalami kesulitan, selain itu produk yang dikembangkan memiliki keterlaksanaan yang sesuai (Kumalasani, 2018). Bukan hanya itu, media terbilang praktis ketika pada hasil uji kepraktisan media pembelajaran yang dikembang mendapat balasan baik entah itu dari guru maupun peserta didik (Nasution et al., 2016). Adapun total respon dapat dilihat pada tabel 6.

Tabel 6. Total Respon Keseluruhan

\begin{tabular}{ccc}
\hline No & Jenis Penilaian & Rata-Rata \\
\hline 1. & Respon Peserta didik & 3,46 \\
\hline 2. & Respon Guru & 3,6 \\
\hline Rata-Rata & Total & $\mathbf{3 , 5 3}$ \\
\hline Kriteria Penilaian & Sangat Praktis \\
\hline
\end{tabular}

Media pembelajaran PowToon untuk menghitung tingkat keefektifannya dilihat berdasarkan kepemahaman peserta didik pada materi. Instrumen pada penelitian ialah soal. Soal digunakan dalam pembelajaran adalah soal pilihan ganda dengan 30 nomor. Pembelajaran bisa dibilang tuntas ketika mencapai skor minimal $80 \%$ bagi peserta didik. Adapun rerata hasil belajar peserta didik yakni 83,54 dengan kategori sangat efektif dan berada pada interval $(>80)$. Hal tersebut dikatakan peserta didik lolos (berhasil) ketika mendapat skor yang tinggi atau setara dengan skor KKM. 
Proses penggunaan media dalam pembelajaran mempunyai pengaruh yang begitu besar pada pemahaman isi pelajaran, dengan menggunakan media pemahaman bisa dikatakan terjamin dengan baik terhadap peserta didik dan dapat pula mempengaruhi semangat belajar sehingga kondisi pembelajaran bisa lebih menyenangkan. Produk pengembangan terbilang efektif jika hasilnya memenuhi tujuan pembelajaran yang diberikan pada tes hasil belajar peserta didik (Haviz, 2016).

Adapun kekurangan dari media PowToon yaitu video yang dihasilkan setelah dikerjakan dengan media ini harus melalui berbagai proses yang terbilang sulit, jaringan yang bersifat stabil dan penggunaannya memerlukan peralatan yaitu PC atau komputer apalagi jika dimanfaatkan pada proses belajar mengajar di kelas itu membutuhkan media tambahan berupa LCD dan pengeras suara agar mendapatkan Audio dan visual yang sangat bagus (Pangestu \& Wafa, 2018).

\section{SIMPULAN}

Kesimpulan penelitian dari media PowToon dikembangkan dengan model 4D melalui 4 tahap utama yaitu (1) define (pendefinisian) yang meliputi analisis awal-akhir, analisis peserta didik, analisis konsep, analisis tugas, dan analisis tujuan pembelajaran, (2) Design (Perancangan) yang meliputi penyusunan tes, pemilihan format, pemilihan media dan perancangan awal, (3) Development (Pengembangan) yang meliputi validasi ahli dan uji coba media pembelajaran biologi materi sel berbasis PowToon dan (4) Disseminate (Penyebaran). tingkat kevalidan memenuhi kategori valid dengan skor ratarata 3,66 sehingga dikatakan layak digunakan, media tergolong praktis karena memiliki skor rata-rata 3,53 sehingga media dikatakan praktis digunakan, dan keefektifan yaitu 83,54 sehingga dikatakan efektif digunakan. Peneliti berharap untuk kedepannya bisa mengembangkan kembali media powtoon ini menjadi lebih baik lagi.

\section{DAFTAR PUSTAKA}

Arum, A. P. (2020). Strategi pembelajaran kooperatif pada mata kuliah penataan rambut. JTP - Jurnal Teknologi Pendidikan, 22(2), 132-139. https://doi.org/10.21009/jtp.v22i2.16490

Arywiantari, D., Agung, A. . G., \& Tastra, I. D. K. (2015). Pengembangan multimedia interaktif pada pembelajaran IPA di SMP Negeri 2 singaraja. Jurnal Edutech Universitas Pendidikan Ganesha, 3(1), 3. ), https://dx.doi.org/10.23887/jeu.v3i1.5611

Deliviana, E. (2017). Aplikasi powtoon sebagai media pembelajaran: manfaat dan problematikanya.

Dwijayani, N. M. (2017). Pengembangan media pembelajaran ICARE. Kreano, Jurnal Matematika Kreatif-Inovatif, $\quad$ 8(2), 126-132. https://doi.org/10.15294/kreano.v8i2.10014

Fajar, S. (2017). Pengaruh penggunaan media PowToon terhadap hasil belajar siswa pada mata pelajaran ilmu pengetahuan sosial terpadu. Jurnal Pengajaran MIPA, 3(2), 101-114. http://ejournal.upi.edu/index.php/edutechnologia/article/view/8957

Fayanto, S., Herawati, R., \& Sulisworo, D. (2019). The development of learning videos on powtoon-based work and energy topics to support flipped classroom learning. 
IOSR Journal of Research \& Method in Education (IOSR-JRME), 9(4), 51-58. https://doi.org/10.9790/1959-0904015158

Hamansah, H., \& Hading, H. (n.d.). Pengaruh penerapan modul stiles biologi sel terhadap peningkatan hasil belajar mahasiswa pada angkatan 2015 jurusan pendidikan biologi fakultas tarbiyah dan keguruan UIN Alauddin Makassar. Jurnal Biotek, 4(1), 150-167. https://doi.org/10.24252/ib.v4i1.1778

Hardiyanti, H., Mustami, M. K., \& Mu'nisa, A. (2020). Pengembangan game puzzle berbasis construct 2 sebagai media pembelajaran sistem peredaran darah kelas XI di SMA Negeri 1 Selayar. Biolearning Journal, 7(1), 6-11. https://doi.org/10.36232/jurnalbiolearning.v7i1.503

Haviz, M. (2016). Research and development; penelitian di bidang kependidikan yang inovatif, produktif dan bermakna. Ta'dib, 16(1). https://dx.doi.org/10.31958/it.v16i1.235

Heryanto, G., \& Rahayu, S. (2021). the Influence of Powtoon Media in Teaching Listening. PROJECT (Professional Journal of English Education), 4(1), 86. https://doi.org/10.22460/project.v4i1.p86-90

Kumalasani, M. P. (2018). Kepraktisan penggunaan multimedia interaktif pada pembelajaran tematik kelas IV SD. Jurnal Bidang Pendidikan Dasar, 2(1A), 1-11. https://doi.org/10.21067/jbpd.v2i1A.2345

Latifah, N., \& Lazulva, L. (2020). Desain dan uji coba media pembelajaran berbasis video animasi powtoon sebagai sumber belajar pada materi sistem periodik unsur. JEDCHEM Journal Education and Chemistry), 2(1), 26-31. https://doi.org/10.24036/jep/voI4-iss2/509

Listiani, D., \& Prihatnani, E. (2018). Pengembangan media pembelajaran dart board math bagi siswa kelas VII SMP. Math Didactic: Jurnal Pendidikan Matematika, 4(1), 2133. https://doi.org/10.33654/math.v4i1.80

Maimunah, M. (2016). Metode penggunaan media pembelajaran. Al-Afkar: Jurnal Keislaman \& Peradaban, 5(1). https://doi.org/10.28944/afkar.v5i1.107

Masita, M., \& Wulandari, D. (2018). Pengembangan buku saku berbasis mind mapping pada pembelajaran IPA. Jurnal Kreatif: Jurnal Kependidikan Dasar, 9(1). https://repository.unja.ac.id/5077/1/artikel\%20skripsi\%20gue.pdf

Megawati, N. M. S., \& IGALP, U. (2020). English learning with Powtoon animation video. Journal of Education Technology, 4(2), 110-119. http://dx.doi.org/10.23887/jet.v4i2.25096

Muntari. (2015). Upaya guru mengatasi kesulitan belajar siswa bidang studi pendidikan agama islam di SD Mujahidin 2 Surabaya. Jurnal Pendidikan Islam, 4(1). http://journal.um-surabaya.ac.id/index.php/Tadarus/article/view/1117/pdf

Nasution, S. H., Anwar, L., Sudirman, \& Susiswo. (2016). Pengembangan media pembelajaran untuk mendukung kemampuan penalaran spasial siswa pada topik dimensi tiga kelas X. Jurnal KIP (Keguruan Dan Ilmu Pendidikan), IV(2), 903-913. http://journals.ukitoraja.ac.id/index.php/jkip/article/view/66

Nor, M., Zuhdi, Z., \& Asbiah, A. (2021). The development of learning media based on powtoon in global warming materials for class XI high school. Journal of Educational Sciences, 5(2), 278. https://doi.org/10.31258/jes.5.2.p.278-286

Nurdiyanti, Mustami, K., \& Ali, A. (2017). Pengembangan buku ajar dan augmented reality 
pada konsep sistem ekskresi di Sekolah Menengah Atas. UNM Journal of Biological Education, 1(1), 23-31. https://ojs.unm.ac.id/UJBE/article/view/5762

Pangestu, M. D., \& Wafa, A. A. (2018). Pengembangan multimedia interaktif PowToon pada mata pelajaran ekonomi pokok bahasan kebijakan moneter untuk siswa kelas xi ips di sma negeri 1 singosari. Jurnal Pendidikan Ekonomi, 11(1), 71-79. http://journal2.um.ac.id/index.php/jpe/article/view/3129/1982

Priyayi, D. F., Keliat, N. R., \& Hastuti, S. P. (2018). Masalah dalam pembelajaran menurut perspektif guru biologi Sekolah Menengah Atas (SMA) di Salatiga dan kabupaten Semarang. Didaktika Biologi: Jurnal Penelitian Pendidikan Biologi, 2(2), 85-92.

Purwono, J. (2014). Penggunaan media audio-visual pada mata pelajaran ilmu pengetahuan alam di Sekolah Menengah Pertama Negeri 1 Pacitan. Jurnal Teknologi Pendidikan Dan Pembelajaran, 2(2). https://jurnal.fkip.uns.ac.id/index.php/tp/article/view/3659

Puspitarini, Y. D., \& Hanif, M. (2019). Using learning media to increase learning motivation in elementary school. Anatolian Journal of Education, 4(2), 53-60. https://doi.org/10.29333/aje.2019.426a

Rahardja, T., \& Umar Dan, S. L. (2005). La Sulo, Pengantar pendidikan, Jakarta: PT. Rineka Cipta, 2(3), 24-45.

Saondi, O., \& Suherman, A. (2015). Etika profesi keguruan.

Setiyadi, M. W. (2017). Pengembangan modul pembelajaran biologi berbasis pendekatan saintifik untuk meningkatkan hasil belajar siswa. Journal of Educational Science and Technology (EST), 3(2), 102-112.

Siti Sapuroh. (2010). Analisis kesulitan belajar siswa dalam memahami konsep biologi pada konsep monera.

Sugiyono, D. (2013). Metode penelitian pendidikan pendekatan kuantitatif, kualitatif dan $R \& D$.

Tafonao, T. (2018). Peranan media pembelajaran dalam meningkatkan minat belajar mahasiswa. Jurnal Komunikasi Pendidikan, 2(2), 103. https://doi.org/10.32585/jkp.v2i2.113

Widoyoko, E. P. (2009). Evaluasi program pembelajaran. Yogyakarta: Pustaka Pelajar, 238.

Zaenal Arifin. (2017). Kriteria instrumen dalam suatu penelitian. Jurnal THEOREMS (The Original Research of Mathematics), 2(1), 28-36. https://dx.doi.org/10.31949/th.v2i1.571 